\title{
Study of Multi-Origin Hazards and Assessment of Associated Risks in the Lefo Caldera (Bamenda Volcano, Cameroon Line)
}

\author{
Zangmo Tefogoum Ghislain 1,2, Nkouathio David Guimolaire'2, Kagou Dongmo Armand2, \\ Gountie Dedzo Merlin ${ }^{3}$, Kamgang Pierre 4 \\ ${ }^{1}$ Department of Earth Sciences, Faculty of Sciences, University of Maroua, Maroua, Cameroon \\ ${ }^{2}$ Department of Earth Sciences, Faculty of Sciences, University of Dschang, Dschang, Cameroon \\ ${ }^{3}$ Department of Life and Earth Science, High Teacher Training College, University of Maroua, \\ Maroua, Cameroon \\ ${ }^{4}$ Department of Earth Sciences, Faculty of Science, University of Yaounde 1, Yaounde, Cameroon \\ Email: zangmotefogoum@gmail.com
}

Received 18 August 2014; revised 15 September 2014; accepted 8 October 2014

Copyright (C) 2014 by authors and Scientific Research Publishing Inc.

This work is licensed under the Creative Commons Attribution International License (CC BY). http://creativecommons.org/licenses/by/4.0/

(c) (i) Open Access

\section{Abstract}

The Bamenda Volcano (BV) (2621 m) is a stratovolcano situated in the Cameroon Line (CL). BV includes Mount Lefo $(2534 \mathrm{~m})$ which is situated on its southern slopes and contains one elliptical caldera $(3 \times 4 \mathrm{~km})$. This caldera is propitious to farming and breeding activity. Despite these profitable assets, Lefo caldera (LC) is an amphitheater of the occurrence of multi-origin hazards that have direct or indirect impacts on the biodiversity and human patrimony. The most present hazards are those of meteorological origin. Numerous combined factors (steepest slopes, heavy rainfalls, weathered state of volcanic products...) rule these hazards. These factors gave rise to the occurrence of landslides, gullies erosion and rock falls which occur precisely on caldera northern and eastern rims. Hazards of anthropogenic origin are based on the destruction of the vegetation cover by the population for dealing, firewood and building issues. Moreover, during the breeding activity, the cattle covers the caldera throughout the day; this unevens the topography and destroys the meadow. Hazards of volcanological origin are not yet occurring in LC; but the recent Lake Monoun (1984) and Nyos (1986) $\mathrm{CO}_{2}$ eruptions, mount Cameroon eruptions (1999 and 2000) and mount Oku Lake event (2011) which are close to the $\mathrm{BV}$ and, the age of 0 Myr of basalt, constitutes a subject of controversy toward the reactivation of the Cameroonian hotspot faults. The assessment of risks in LC was based on the average income of breeding activity and house investment. The economy of LC is valued at about US\$527472.527. The level of such risk will be important in case of loss of human beings and the destruction of geomorphosites' values. In order to reduce the level of looses in this zone, hazard and risks maps are provided in this paper as well as some recommendations. 


\section{Keywords}

\section{Hazards, Risk, Anthropogenic Activities, Lefo Caldera}

\section{Introduction}

The Cameroon country is crossed by a particular geological structure called Cameroon Line (CL) (Figure 1). It is an oceano-continental axis (1600 km length and $100 \mathrm{~km}$ width) that stretches from the Gulf of Guinea (Atlantic Ocean) until the Lake Chad (African Continent) and is oriented N30 ${ }^{\circ} \mathrm{E}$. LC is made up of volcanic apparatus (Cameroon, Manengouba, Bambouto, Bamenda, Oku and Rumpi) and plutonic complexes (Koupé, Nlonako, Bana, Kapsiki...) [1]-[3].

Volcanic apparatus of the CL present relevant economical assets; therefore, they are liable to the settlement of active agropastoral multi-ethnic populations although the occurrence of numerous disastrous hazards. Accordingly, some studies focused on hazards and related risks have been carried out in some CL's volcanoes in order to mitigate and reduce the risks rate in case of hazards [4]-[14]. The Bamenda volcano (BV) that has not yet constituted the subject of detailed hazards studies, interests us in this paper. It is pierced by two separated calderas: Santa-Mbu and Lefo caldera (LC). LC has been chosen as the study area for this work. That's why we devoted the aim of this work to the study of hazards of multiple origins that occur in LC and their related impacts

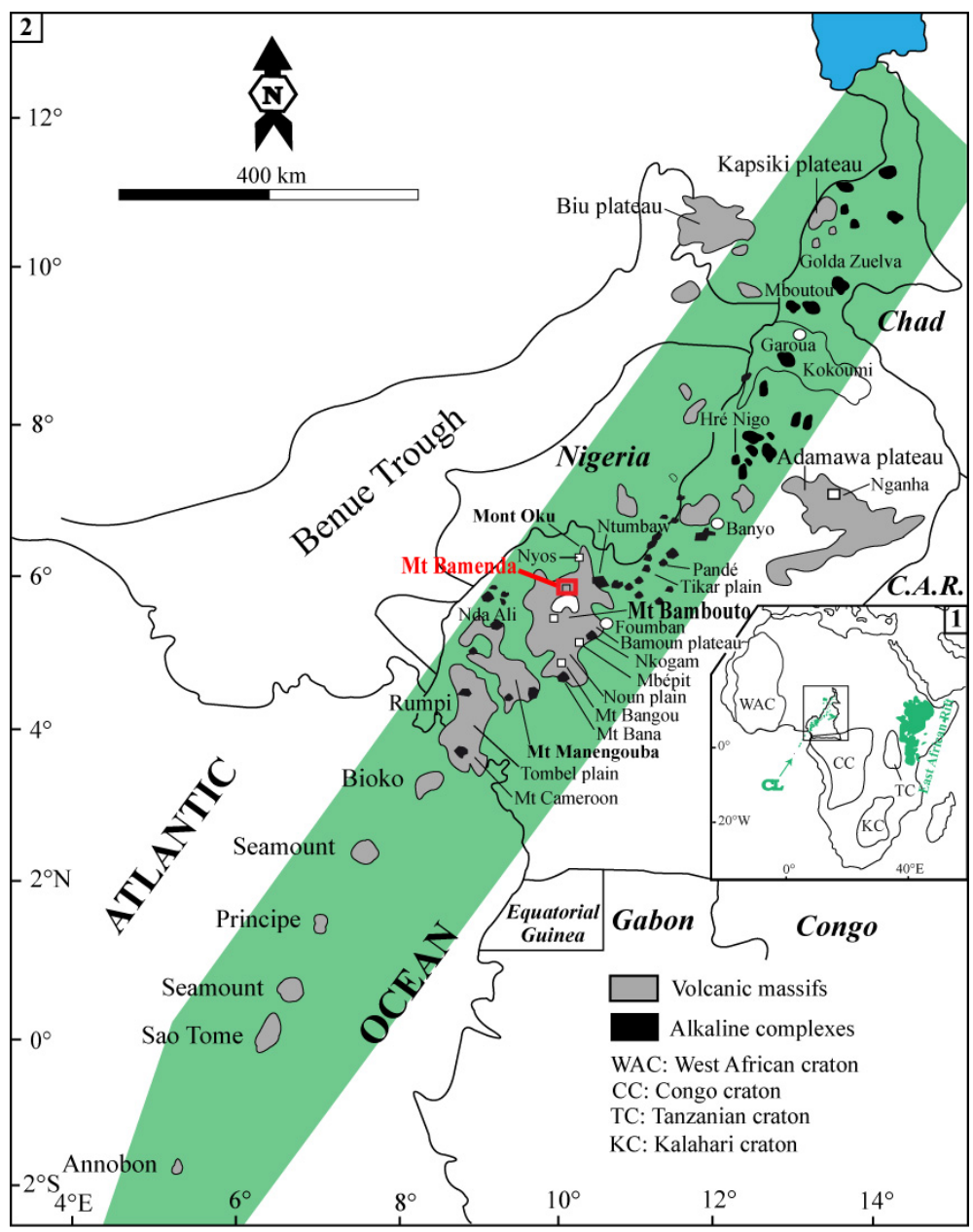

Figure 1. Cameroon Line (CL) in Africa (1); Location of Mt Bamenda in CL (2). 
on biodiversity and human patrimony.

\section{Geological Context of the Study Area}

LC appears as the smallest caldera of BV an is elliptical in shape $(3 \times 4 \mathrm{~km})$ opened to the south-east. It was developed by successive emplacement from 0 to 27, 4 Myrs on the south-eastern slopes of BV precisely between $10^{\circ} 11^{\prime}-10^{\circ} 15^{\prime} \mathrm{E}$ and $05^{\circ} 46^{\prime}-05^{\circ} 50^{\prime} \mathrm{N}$. Its basement consists of Pan-African granitoids [15]-[17]. The maximum height of LC is $2534 \mathrm{~m}$; it is found on the northern rim of the caldera at mount Lefo. LC isolates two main depressions: in the East, the Ndop plain (1600 m - $1400 \mathrm{~m}$ deep) and in the west, a huge valley (1900 m - $1400 \mathrm{~m}$ deep). The Caldera appears fairly flat with altitudes ranging between $1800 \mathrm{~m}$ and $1600 \mathrm{~m}$. It is strewn with domes of trachytic and ignimbritic nature that uneven the general topography of the massif. The caldera western and northern rims are made up of prismatic trachytic walls appearing in landings and constitute the witnesses of the caldera collapse [18].

\section{Typology of Hazards}

Numerous hazards are found in LC; they are classified according to the type of their triggering factors. The most common hazards in the region are those of meteorological, anthropogenic and volcanological origin.

\subsection{Hazards of Meteorological Origin}

These hazards include mass movements (rock falls, debris falls and landslides) and the effect of high velocity of wind on the goods. Mass movements in LC are triggered by the combination of predisposing and triggering factors.

\subsubsection{Predisposing Factors}

The predisposing factors of mass movements include: lithology, structural setting, climate, slope morphology, vegetation cover and land use.

\section{- Lithology}

The lithology of LC (Figure 2) is dominated by a succession of several types of rocks such as basalts, basanites, trachytes and ignimbrites [19]-[21]. These petrographic units are overlaid by crumbly and loose materials. Most of them crop out in cracked columns mainly in the northern, eastern and western rims (Figure 3).

\section{- Structural setting}

The structural setting of LC is highlighted by fractures and geological contacts. The hydrographic network

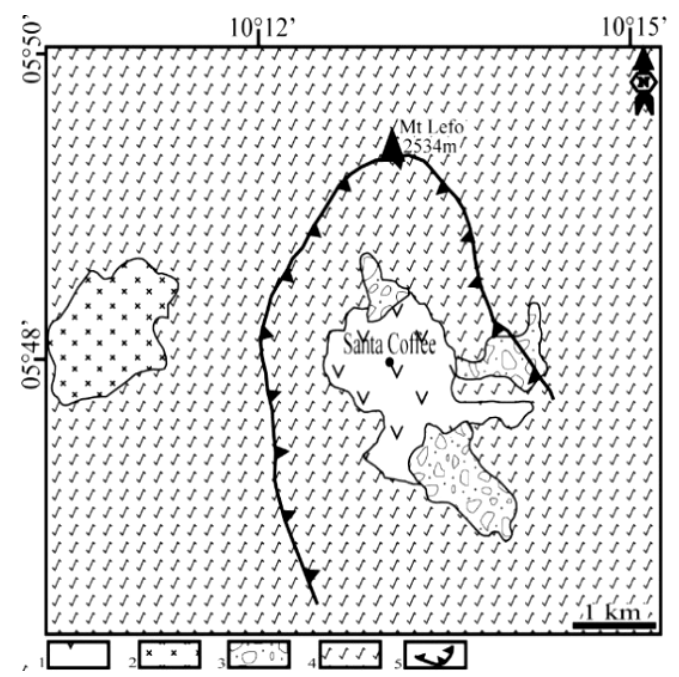

Figure 2. Geological map of the LC. 1-Basalts; 2 - Basanites; 3-Ignimbrites; 4-Trachytes; 5Caldera boundaries. 
(Figure 4) of the region is slightly dense and is of sub-parallel type, dominated by permanent and seasonal streams.

It is indicative of the basement fractures system induced by the large-scale Precambrian fault reactivation [22]. The relation between lithological units of LC testifying the geological contacts can be observed on cross sections (Figure 5) realised from the geological map.

\section{- Climate}

Since LC is a mountainous region, the climate conditions are aggressive and they are Sudanese Tropical type [23] [24] with the dry season from November to March and the rainy season from April to October. The temperatures are ganged between $23^{\circ} \mathrm{C}$ and $17^{\circ} \mathrm{C}[25]$ and the wind currents are violent.

\section{- Slope morphology}

The slope morphology in LC is heterogeneous. Figure 6 highlights the classes of slopes that are found in the caldera and its vicinity; notably: plate, wavy, undulating, uneven and steep slopes.

Method of the realization of slopes morphology map: As in a whole set of GIS software, slope maps used in this study have been calculated from a Digital Elevation Model $(D E M)$ with a $30 \times 30 \mathrm{~m}$ spatial resolution using ILWIS (Integrated Land and Water Investigation Software). The DEM was provided by the online database of the U.S. Geological Survey: http://gdex.cr.usgs.gov/gdex/.

The calculation consists of three steps. Firstly, two gradient filters are calculated and saved as layers (Dx and $D y)$. i.e. the filter which detects slope differences in $x$-direction (DFDX), and the filter which detects slope differences in y-direction (DFDY). Secondly, the slope map is calculated by typing the following formula in the Map calculation command line: Slope (degrees $)=$ RADDEG $(A T A N((H Y P(D x, D y)) /$ pixsize $($ Dem $)))$.

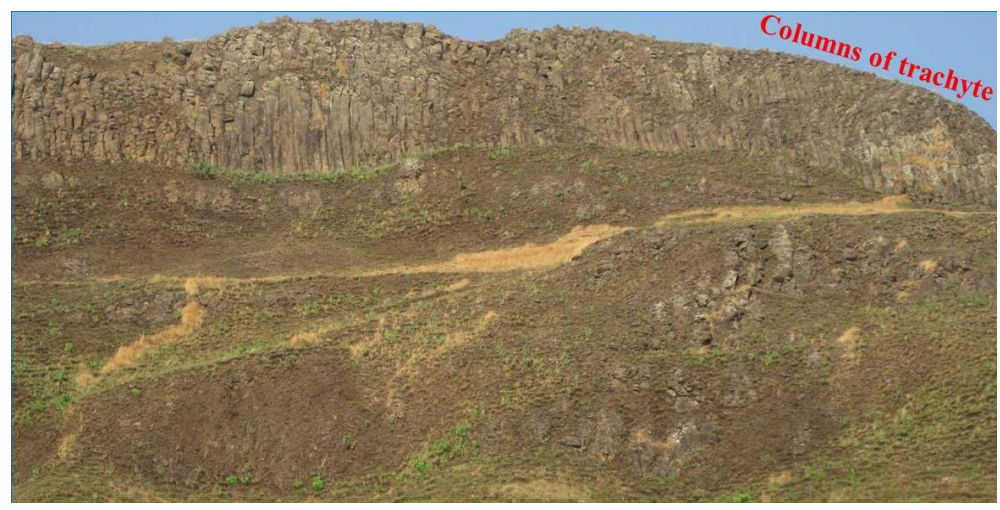

Figure 3. Cracked columns of trachyte in the western rim of LC.

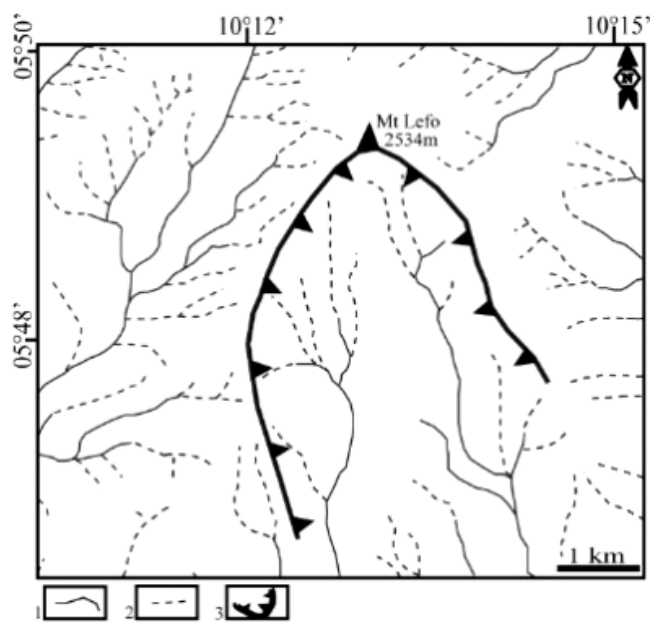

Figure 4. Hydrographic network of LC. 1-Permanent streams; 2-Seasonal streams; 3-Caldera boundaries. 

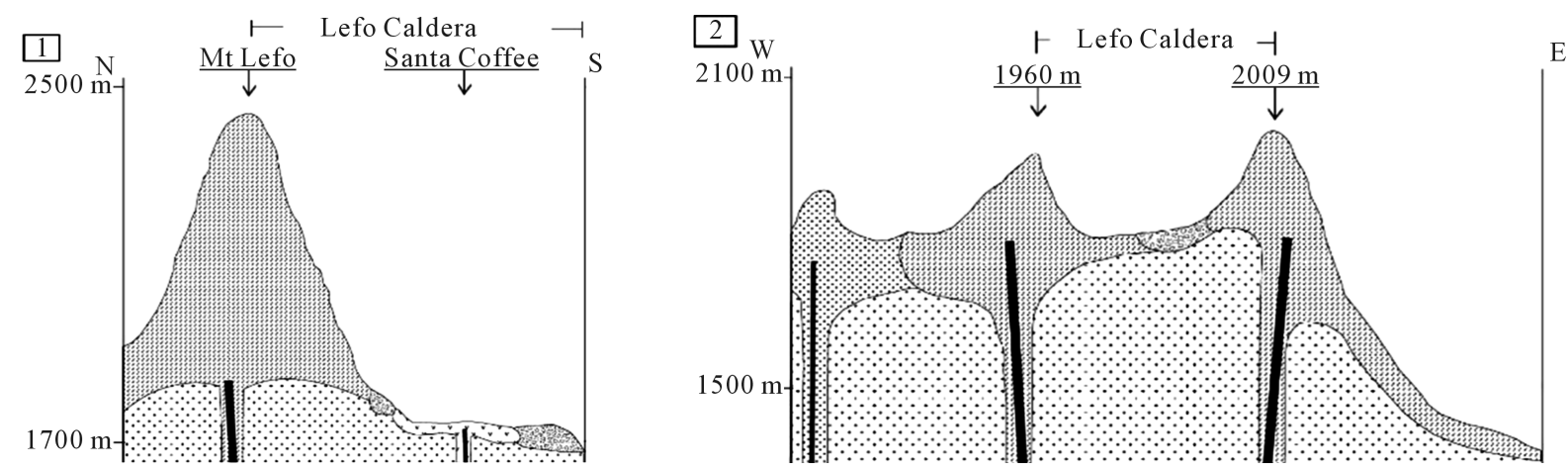

Figure 5. Cross sections ( $1 \& 2$ ) of LC (symbols correspond to that of Figure 2).

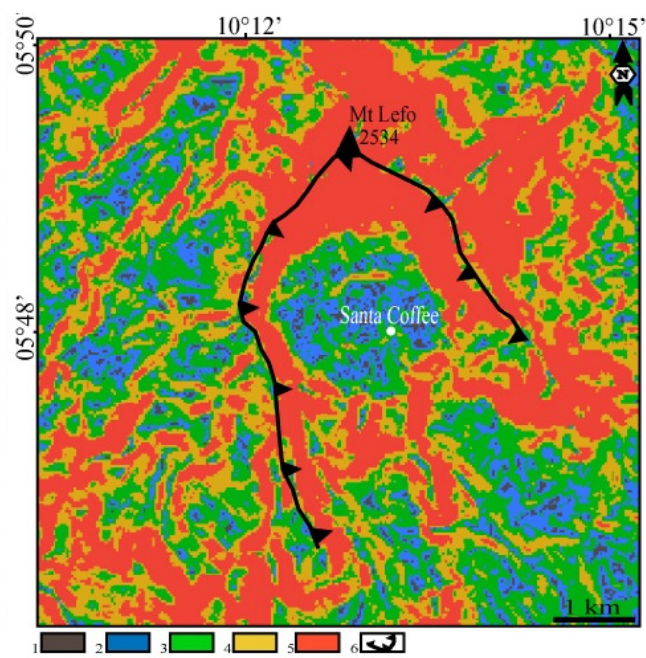

Figure 6. Slopes map of LC. 1 -Plate $\left(0^{\circ}-2^{\circ}\right) ; 2$

-Wavy $\left(2^{\circ}-5^{\circ}\right)$; 3-Undulating $\left(5^{\circ}-10^{\circ}\right) ; 4$ Uneven $\left(10^{\circ}-15^{\circ}\right)$; 5-Steep $\left(15^{\circ}-81^{\circ}\right)$; 6-

Caldera boundaries.

In this formula HYP (hypotenuse) is an internal map calculation function to determine the positive root of the sum of square Dx plus square Dy (Pythagoras rule). The ATAN function calculates the $\arctan \left(\tan ^{-1}\right)$, and returns real values in radians in the range $-1 / 2 \pi$ to $1 / 2 \pi$. The function RADDEG is used to convert the radians to degrees.

Finally, the slope map is sliced by grouping the slope values into a set of classes according to the different ranges which better illustrate the five classes of slopes that can influence or not mass movement hazards.

The wavy class appear much distributed in the caldera floor and in the valleys close to the caldera. The steep class appears on the caldera rims and on escarpments related to the caldera system.

\section{- Vegetation cover}

The vegetation of LC (Figure 7) is characterized by meadow that is dominated by grasses, the forest is absent in the whole caldera. However, there are some colonies of trees (made up mainly of eucalyptus) scattered in the caldera floor and small forest reserve in the north external slopes of LC. Trees and grasses play a significant role in the weathering of rock by cracking them (Figure 8).

\section{- Land use}

LC has natural trumps that attract important active population including Bamenda, Bakossi and Bororo people who are estimated at around 60 persons. Leading activities are farming and breeding. They are practiced throughout the year. Land use system is poor. Agriculture is led on the caldera's floor precisely on flat areas (Figure 9). Farmers' houses and a primary school are built on the Northern piedmont of LC. Breeding (Figure 10 ) is led on the most uneven areas (internal and external slopes) of the caldera. To avoid any conflict, some 


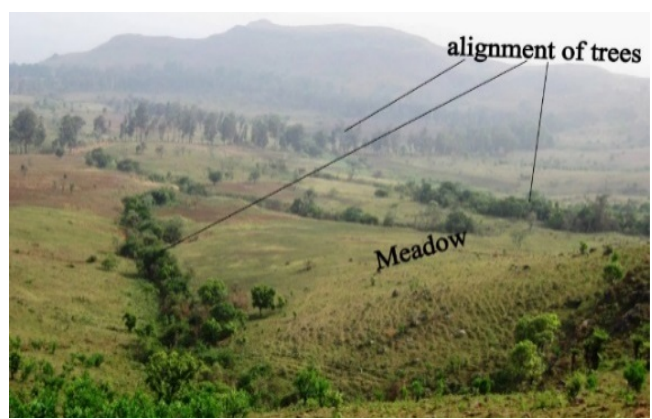

Figure 7. Distribution of the vegetation cover components in LC.

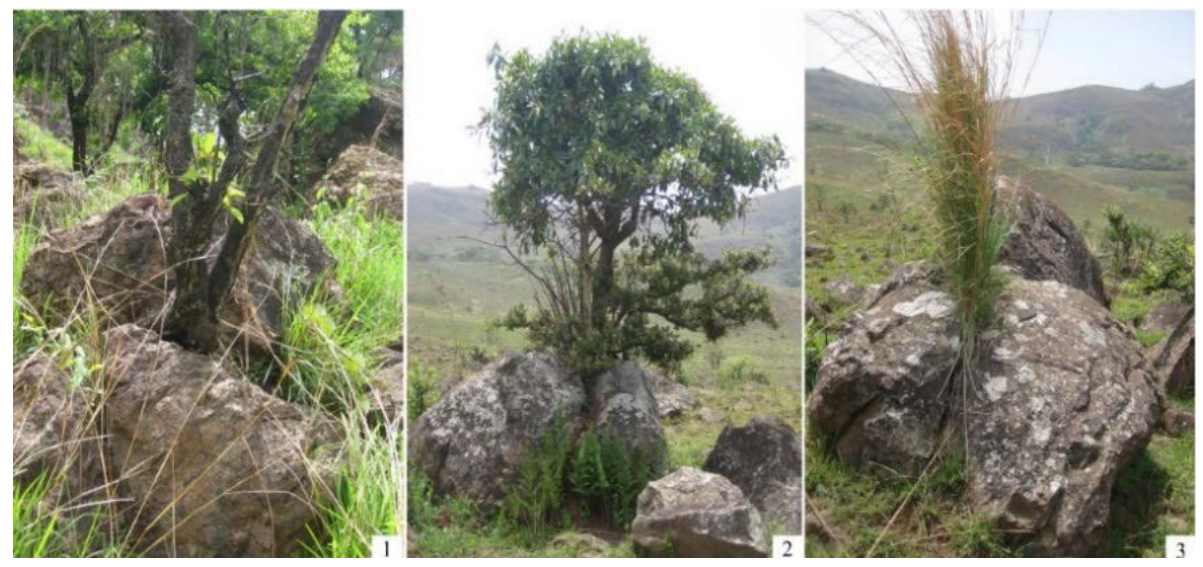

Figure 8. Impacts of vegetation cover (1, 2 \& 3) components rock.

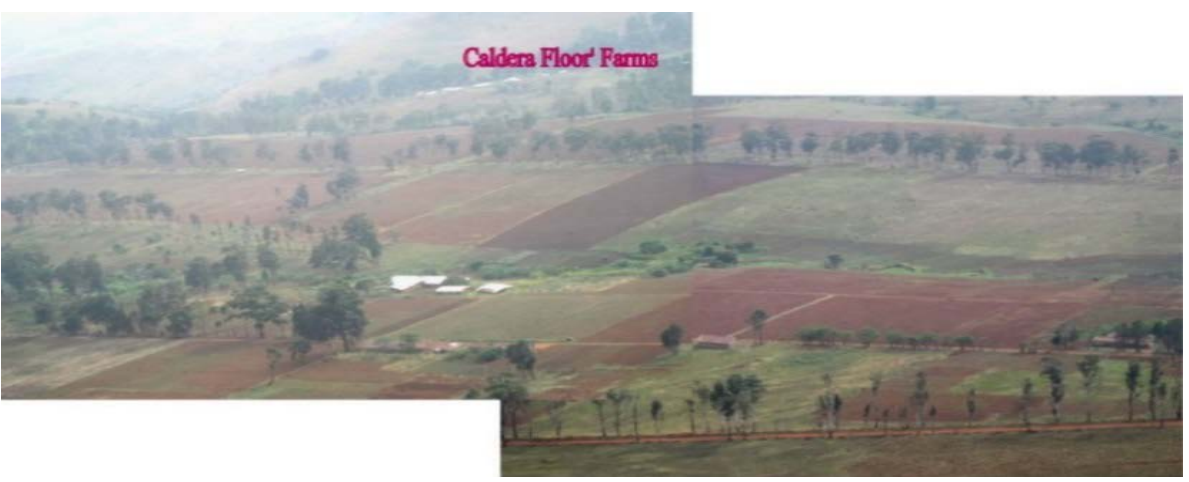

Figure 9. Agriculture in LC.
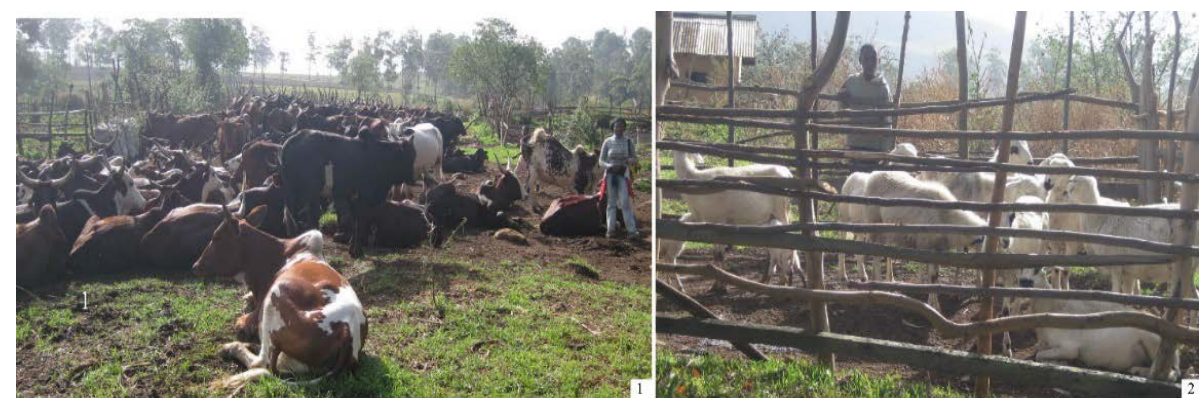

Figure 10. Cattle of breeding activities. 1-Beef; 2-Sheep. 
breeders stay on the crest line of the caldera.

\subsubsection{Triggering Factors}

In many cases triggering factors of mass movements can be at short term and middle term. In LC, triggering factors include extreme meteorological events and human activities.

\section{- Extreme meteorological events}

Extreme meteorological events include long-lasting rainfalls that occur precisely in June, July, August and September (Figure 11). The annual rainfall is around $2596 \mathrm{~mm}$. Long-lasting rainfalls are accompanied by violent wind currents that scan the entire caldera. Their actions are favored by the south-east opening and the altitude of LC.

\section{- Human activities}

Human activities that can trigger mass movements in LC are the opening of road and pedestran tracks, road traffic, excavation and use of engines during farming activities.

Meteorological crises and human activities (farming and breeding) led to the deposition of boundless mellow and crumbly cover with low instability at the basement (presence of sliding zones). This situation favors the occurrence of phenomena such as rocks falls (Figure 12), landslides (Figure 13) and debris falls (Figure 14) in LC. The classification of landslide is based on the type of involved materials, type of movement and movement

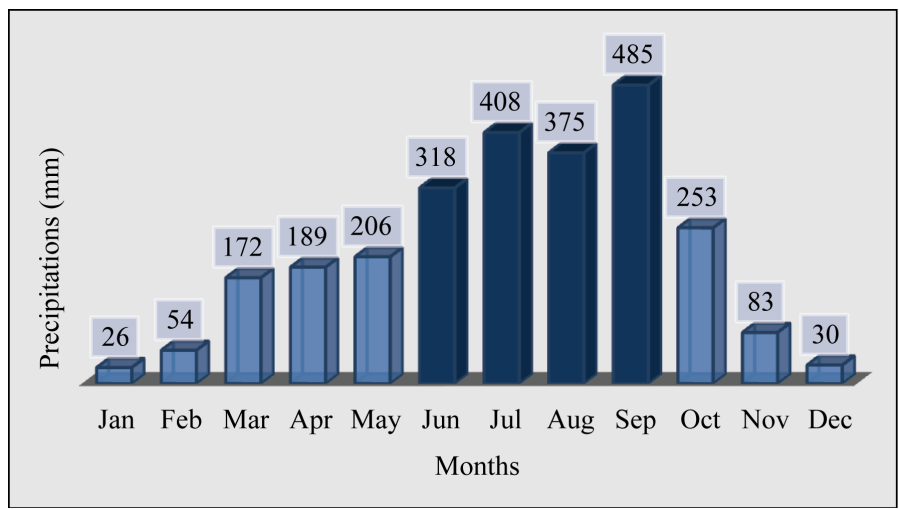

Figure 11. Histogram of precipitations in Bamenda region.

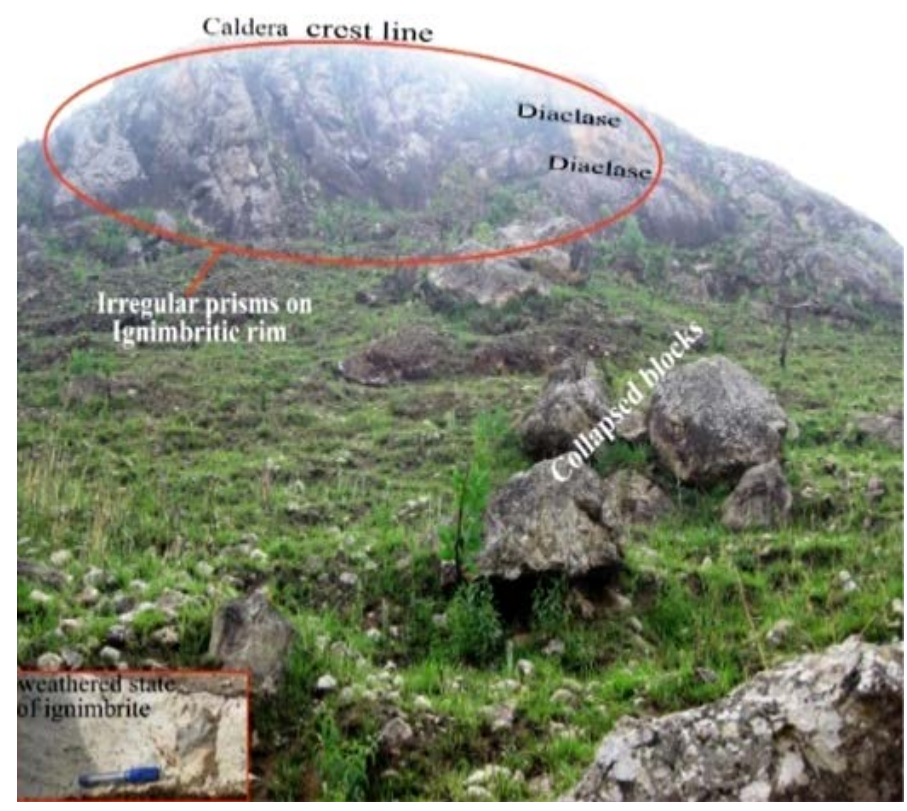

Figure 12. Rock falls on the east rim of LC. 


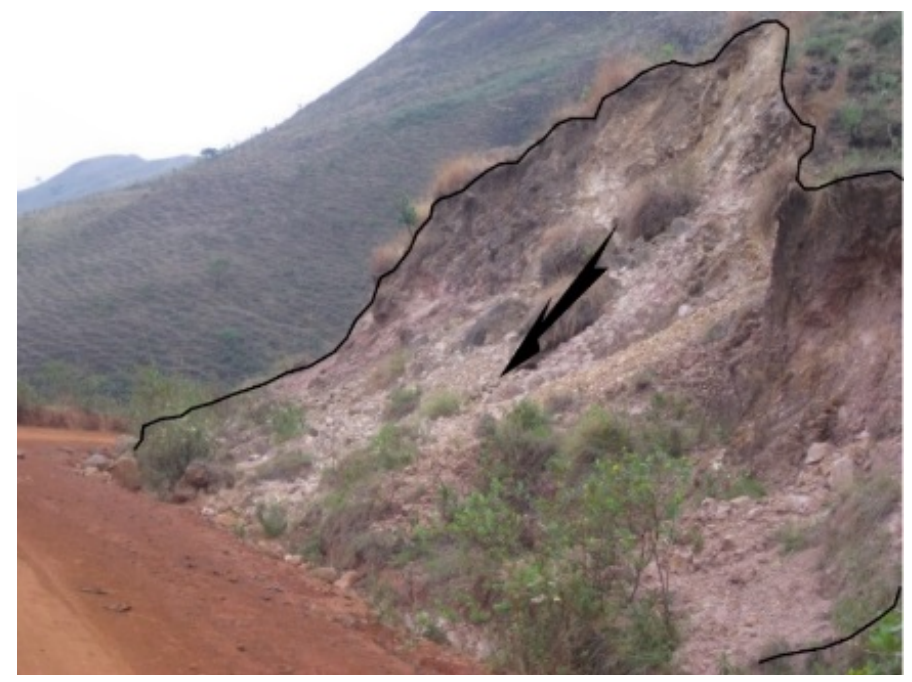

Figure 13. Landslides on the road embankment in LC.

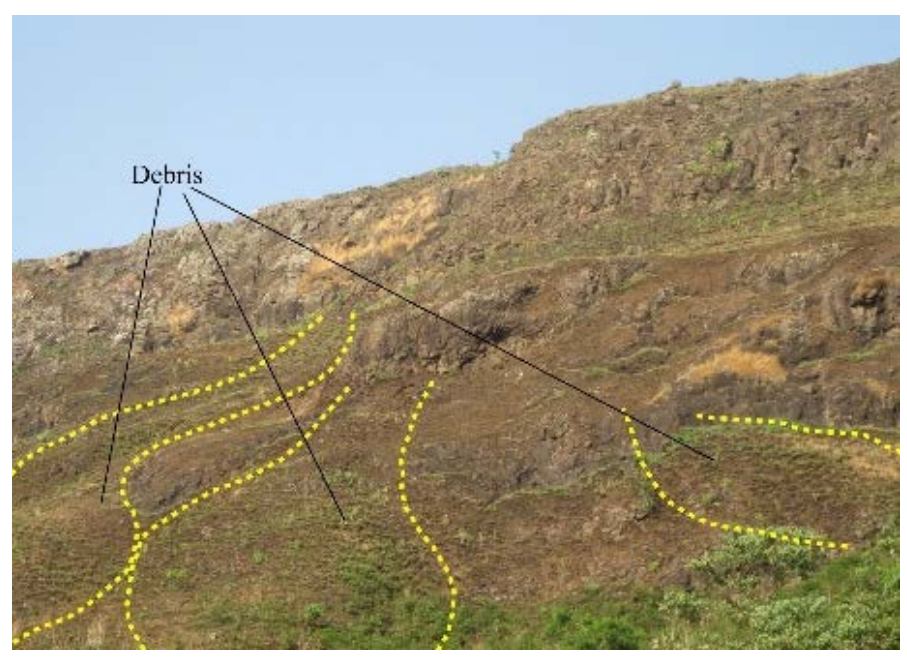

Figure 14. Debris falls on the west rim of LC.

velocity [26]. Landslides in LC are generally translational and are usually rapid due to the high slope of pre-existing weakness plan.

Moreover, basement fissures induced the formation of deeper (2 - $3 \mathrm{~m})$ and longer (15 - $50 \mathrm{~m})$ gullies scattered in the northern slopes of LC (Figure 15).

Figure 16 is the thematic map of mass movements hazards in LC; it shows that $52 \%$ of the region is predisposed to undergo mass movements. The wind current has a real impact in the mobilization of debris and on house's sheet-metal (Figure 17).

\subsection{Hazards of Anthropological Origin}

The vegetation cover is threatened during human activities; trees are cut by some families for dealing, firewood and building issues and for farms enlargement (Figure 18).

Moreover, during the breeding activity, the cattle covers the caldera throughout the day; this destroys the meadow and uneven the topography (Figure 19).

\subsection{Hazards of Volcanological Origin}

These hazards are absent in the LC but the recent phenomena recorded in some CL's volcanoes: recent Lake 


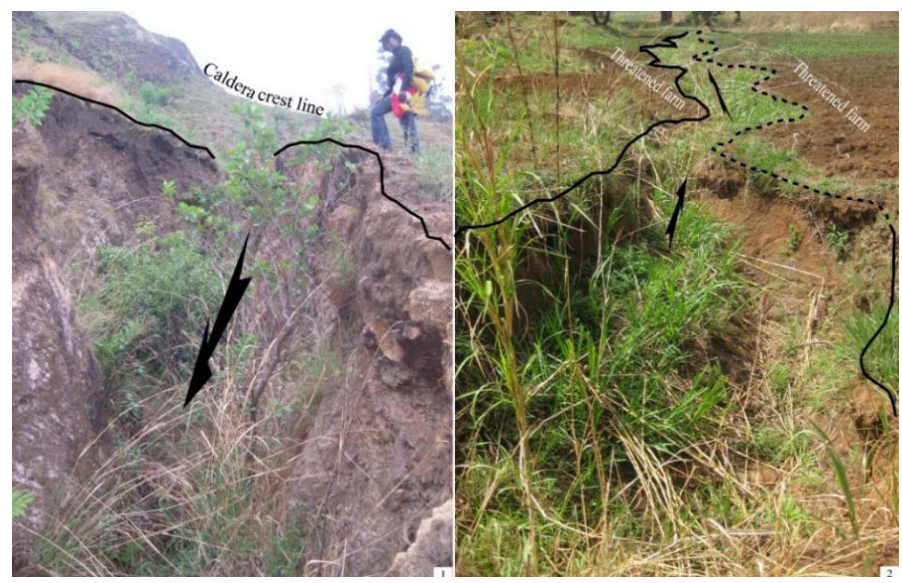

Figure 15. Gullies erosion (1 \& 2) in LC.

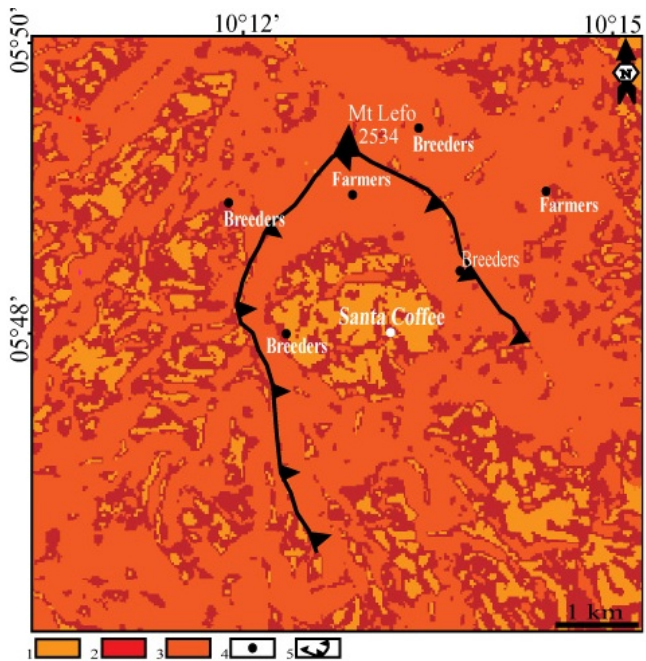

Figure 16. Mass movements hazard map of the LC: 1-Area of low probability of occurrence of mass movements; 2-Area of average probability of occurrence; 3-Area of high probability of occurrence; 4-Inhabitant Camps; 5-Caldera boundaries.

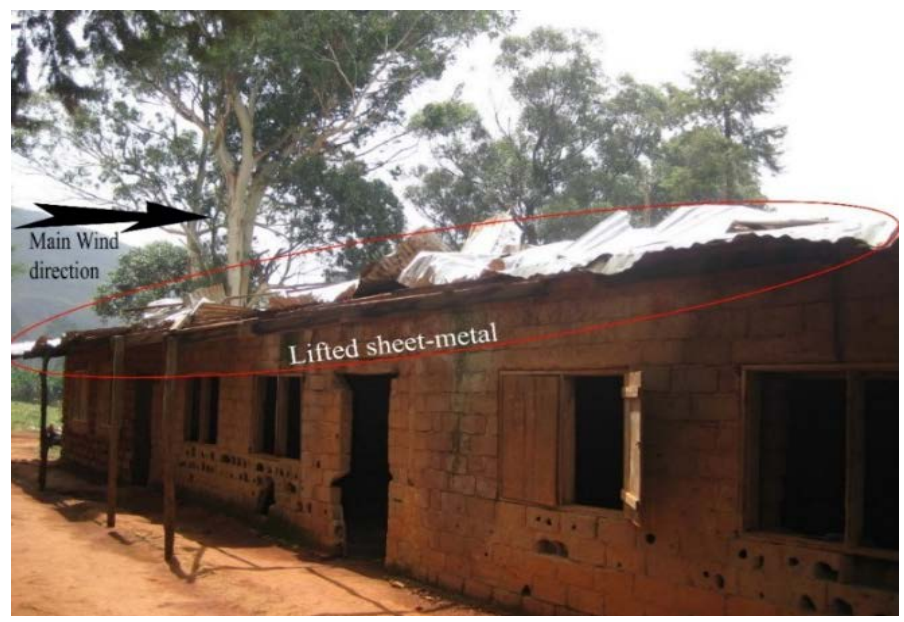

Figure 17. Effect of wind on sheet-metal of the school hall. 


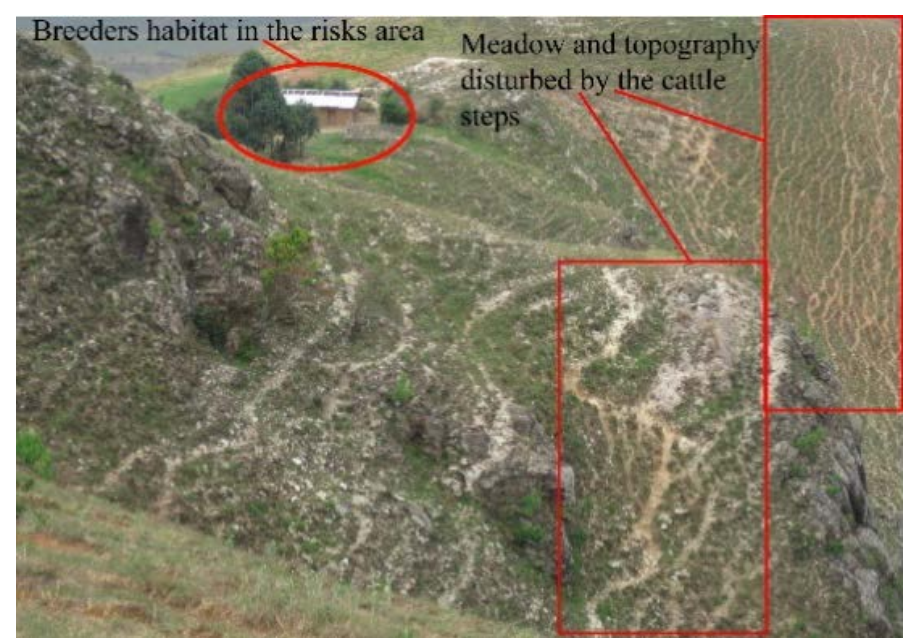

Figure 18. Impact of breeding activity on grasses and topographies on the eastern rim of LC.

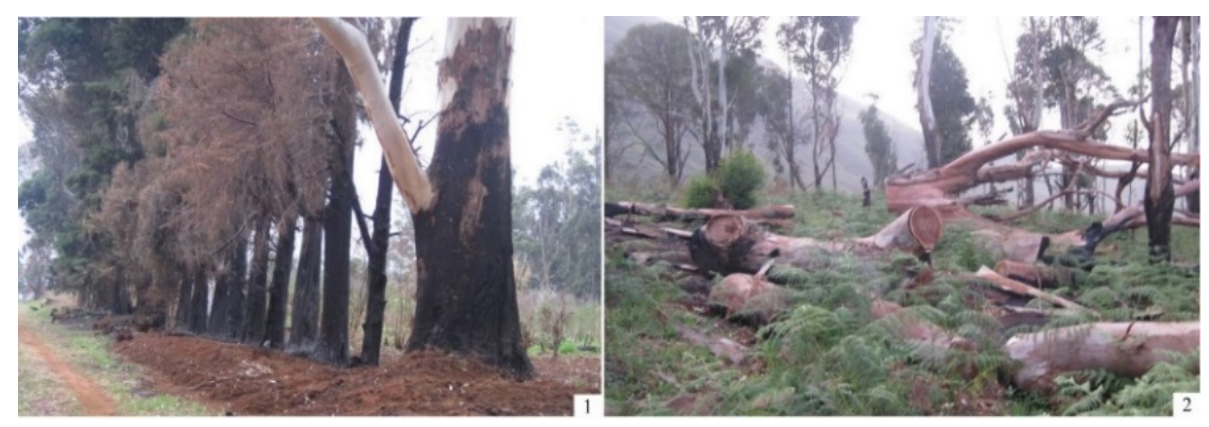

Figure 19. Destruction (1 \& 2) of trees on caldera floor.

Monoun and Nyos $\mathrm{CO}_{2}$ eruptions (respectively in 1984 and 1986), the mount Cameroon eruptions in 1999 and 2000 as well as that of mount Oku Lake in 2011 close to BV (Figure 20) and the faults system (Figure 21) constitute a subject of controversy toward the reactivation of the Cameroonian hotspot faults. Moreover the age of 0 Myr obtained on mafic rock (Basalt) in the BV testify that volcanic activities can resume at anytime in the massif in general and in LC in particular.

The biodiversity, human beings and human patrimony in LC will be affected by lava flows and pyroclastic explosions (Figure 22). The interior of the caldera that is the most coveted by the population will be hugely damaged as well as breeder's houses constructed on steepest slopes.

\section{Risks Assessment}

The assessment of risk in the LC is based on the economical income from breeding activity and house investments (Table 1). The breeding activity consists of raising cattle and sheep. Investments are made on the building of offices, farmers and breeders houses. However the agriculture is focused mainly on coffee, Potatoes, carrot, maize. The cultivation of coffee in LC is dominant; indeed, the amphitheater is called Santa Coffee Estate. Although the agricultural activity has not been assessed because of professional secrecy, it remains the leading activity that has the best income in the region.

LC constitutes a geosite made up of several geomophological units (domes, escarpments and valleys) called geomorphosites. The rarity, the uniqueness, the history and the dynamic of such geomorphosites gave rise to student training, geotourism and many recreational manifestations in the region. Geotourism is one of the best activities which can improve the economical situation of LC'inhabitants; therefore it must be developed. LC geomorphosites are characterized by ecological value due to the fact that they are the support of flora and fauna species in the region. 


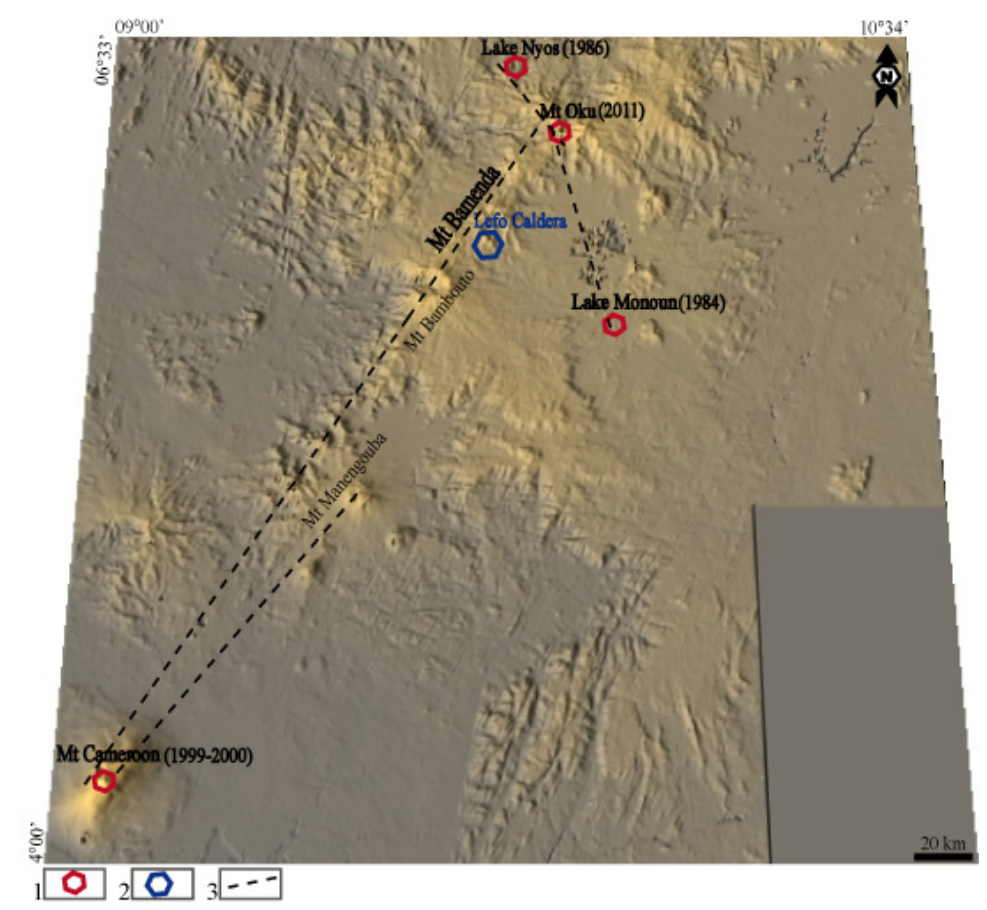

Figure 20. Position of LC between active volcanoes in LC. 1-Active volcanoes; 2-LC; 3-Faults.

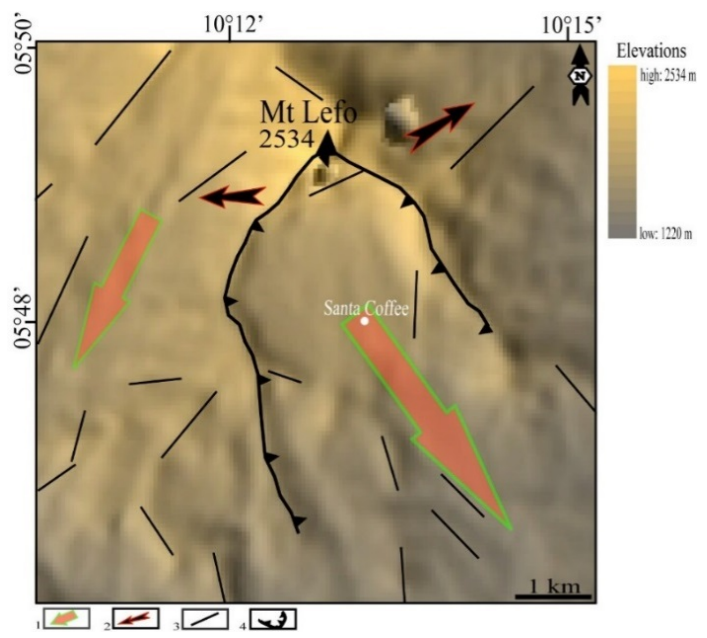

Figure 21. Faults system in LC. 1-Major direction; 2-Minor direction; 3-Faults; 4-Caldera boundaries.

Table 1. Income of breeding activity and house investments.

\begin{tabular}{ccccc}
\hline & & Average units & Average unit costs (FCFA) & Total costs (FCFA) \\
\hline \multirow{2}{*}{ Areeding } & Beefs & 390 & 300,000 & $136,500,000$ \\
& Sheeps & 100 & 35,000 & $3,500,000$ \\
Investments & HOUSES & 50 & $2,000,000$ & $100,000,000$ \\
& & & & $240,000,000$ FCFA \\
& Total & & $\approx$ US\$527472.527 \\
\hline
\end{tabular}




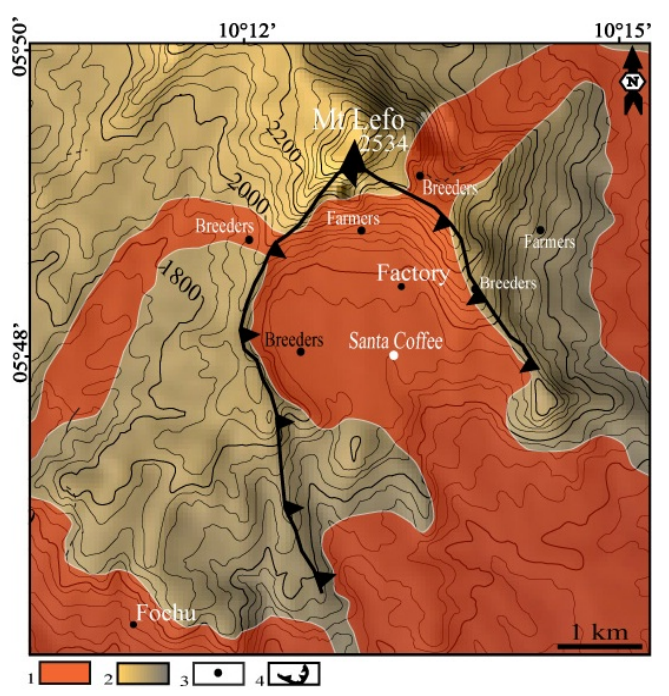

Figure 22. Volcanological hazard map of the LC: 1 -Areas to be covered by lava flows; 2 - Area to be covered by pyroclastic products; 3-Inhabitants camps; 4 -Caldera boundaries.

\section{Discussions}

LC is threatened by three main types of hazards. The hazards of meteorological origin are the most widespread in the region. Landslide and rock falls are most representative. They are ruled by the combination of several predisposing and triggering factors. The climatic conditions are very aggressive on the geological features. The level of rain is very high during rainy months and wind current velocity is significant. Waters penetrate the weakness zones of rocks (spaces between columns and fissures) and create multiple cracks that are in some cases induced by vegetation components roots. Moreover, water also percolates into the ground and is responsible of soil overloading and deep-seated weathering. The vegetation components are mainly meadow (grasses) and small colonies of eucalyptus; accordingly root reinforcement is lacking. This is probably because tree roots do not penetrate below the soil cover. The increasing impact of human activities, such as intensive agriculture, quarrying, road construction, urbanization, land use changes, etc., is also responsible for slope instability and landslide hazard [27] [28]. Although the thin vegetation cover, the hazards of anthropogenic origin are still occurring and constitute the main threat of vegetation cover. They are attributed to the worst behavior of the living people vis-à-vis natural resources that are the main attraction. This is related to the fact that human activities need green spaces. That is why the famers and breeders settled and led their activities respectively on the caldera floor and on uneven areas of LC. Accordingly, vegetation cover is disturbed for dealing, firewood and building issues and for farms enlargement. During farming and breeding, soils are disturbed and rehandled and, become mellowed and denuded. Moreover, techniques as bushfires, and tree roots burning used during respectively the early stage of farming and deforestation, probably increase the green house gases in the region. Moreover, the loss of cohesion as the saturation front reaches the basis of the root belt, has been shown to cause numerous shallow landslides in parts of Brazil [29]. Slopes are much diversified in LC; indeed, subsurface and surface materials on the uneven and steepest slopes in the conditions mentioned above, can be mobilized under the influence of some factors notably, pouring rainfalls, high velocity wind currents. Rocks falls, debris falls and landslides are the frequent hazards of meteorological origin in the caldera that occur on steepest slopes with significant negative impacts on biodiversity and human patrimony.

Hazards of volcanological origin are not occurring in LC. However, in view of recent phenomena recorded in some CL's volcanoes close to BV and, structural and geochronological data, the volcanic activities can resume at anytime. The lithology of the region is indicative of type of eruption. The outcropping of basalts, Basantes, trachytes and ignimbrites testify that eruptions in LC could be mixed and will include fissural, extrusive and explosive types.

The negative effects of landslides are generally more pronounced in developing countries because of their 
high "social vulnerability" to natural disasters, due to economical, social, political and cultural constraints [30]. In LC the risks rate is mainly influenced by the unconsciousness of the growing population about natural hazards. In the care of fighting again poverty and improving the living conditions, the population migrated and settled in the caldera (some on steepest slopes). However, the risks assessed at about US\$527472.527 were focused on breeding income and house investments. This amount is not negligible although the fact that the assessment did not take into account the income of farming activity which seems to be the most profitable activity in the region. Moreover the risks in LC will be enormous in case of loss of human beings (estimated at about 60 people) and the destruction of values of geomophosites.

\section{Conclusions}

LC is an amphitheater tormented by numerous natural and man-made hazards. Hazards of meteorological origin (rock falls, debris falls and landslides) are the most frequent and well distributed hazards. They are ruled by the combination of natural and human factors. Hazards of anthropogenic origin are attributed to the unconsciousness of the population. Hazards of volcanological origin are not found actually in LC but some indices testify the resumption of volcanic activities at anytime. The economical assets of the region gave rise to the settlement of active population that leads the cost-effective breeding and farming activities. This situation increases the level of risk; indeed, the recommendations become compulsory:

- Populations must be sensitized about natural hazards that they are facing and on climate change. Indeed, documents highlighting relevant example of such hazards in some threatened localities around the world must be provided to the population. Risks map produced in this paper can be used as a tool to draw the attention of LC inhabitants. Some panels most be installed in LC, indicating the prohibited area for constructions and activities. Moreover, experts on climate change must explain to the population the negative effect of deforestation and bushfires on the climate.

- Avoid deforestation, bushfires and implement reforestation.

- Amalgamate the stock breeders in a single location and create stock farms to avoid over pasturing.

- Politics must take into account hazards and risks maps during the management of the LC.

\section{Acknowledgements}

This work was validated after slight discussions with the late Professor Wandji Pierre who has deceased in April 2014; our posthumously thanks are addressed to him. The authors thank the Executive committee of the International Association of Geomorphologists for their support to attending the training course on landslide mapping in Dessie (Ethiopia) that helps them to improve the brand of this work. They also express their gratitude right side the traditional authorities for their hospitality during the field works.

\section{References}

[1] Tchoua M.F. (1974) Contribution à l'étude géologique et pétrographique de quelques volcans de la Ligne du Cameroun. (Monts Manengouba et Bambouto). Thèse Doct. Etat, Univ. Clermont-Ferrand, 337.

[2] Fitton, J.G. (1987) The Cameroon Line, West-Africa: A Comparison between Oceanic and Continental Alkaline Volcanism. In: Fitton, J.G. and Upton, B.G.J., Eds., Alkaline Igneous Rocks, Geol. Soc. Special Publication, London, 273-291.

[3] Déruelle, B., Moreau, C., Nkoumbou, C., Kambou, R., Lissom, J., Njonfang, E., Ghogomu, R.T. and Nono, A. (1991) The Cameroon Line: A Review. In: Kampunzuet, A.B. and Lubala, R.T., Eds., Magmatism in Extensional Structural Settings, Springer-Verlag, Heildelberg, 274-327.

[4] Bardintzeff, J.M., Déruelle, B., Wandji, P., Ngounouno, I., Lissom, J., Nkouathio, D. and Fosso, J. (2001) Les éruptions 1999-2000 du mont Cameroun et les risques associés. GSAf 12: Geo-Environnemental Catastrophes in Africa. Journal of Cameron Geoscience Society, 1, 29-30.

[5] Ghogomu, T.R., Tangumonkem, E.T., Tiethop, A.C. and Linonge, O.N. (2001) Landslides in the Bamboutos Region, Western Cameroon. GSAf 12: Geo-Environnemental Catastrophes in Africa. Journal of Cameron Geoscience Society, 1, 54-55.

[6] KagouDongmo, A., Wandji, P., Pouclet, A., Nkouathio, D.G. and Tchoua, F.M. (2005) Le mont Manengouba (Ligne du Cameroun), Un volcan bénéfique, mais potentiellement dangereux, typologie des aléas et évaluation des risques naturels associés. Africa Geoscience Review, 12, 97-109. 
[7] Zoning, A., Ngouanet, C. and Tiofack, O. (2007) The Catastrophic Geomorphological Processes in Humid Tropical Africa: A Case Study of the Recent Landslide Disasters in Cameroon. Sedimentary Geology, 199, 13-27. http://dx.doi.org/10.1016/j.sedgeo.2006.03.030

[8] Zangmo Tefogoum, G., KagouDongmo, A., Nkouathio, D.G. and Wandji, P. (2009) Typology of Natural Hazards and Assessment of Associated Risks in the Mounts Bambouto Caldera (Cameroon Line, West-Cameroon). ActaGeologicaSinica, 5, 1008-1016. http://dx.doi.org/10.1111/j.1755-6724.2009.00130.x

[9] Zangmo Tefogoum, G., KagouDongmo, A., Nkouathio, D.G. and Wandji, P. (2011) Hazards Zonation and Assessment of the Associated Risks in the Mount Manengouba Calderas (Cameroon Volcanic Line). IAG Regional Conference, Addis Ababa, 146.

[10] Zangmo Tefogoum, G., KagouDongmo, A., Nkouathio, D.G., Wandji, P., GountieDedzo, M., Kamgang, P. and Nono, A. (2012) Multi-Hazard Study and Assessment of Associated Risks in the Lefo Caldera of Bamenda Volcano (Cameroon Volcanic Line). The Magmatic Rifting and Active Volcanism Conference, Addis Ababa, 166-167.

[11] Zangmo Tefogoum, G., Nkouathio, D.G., Kagou Dongmo, A., Wandji, P. and Gountie Dedzo, M. (2013) Study of Landslide hazards and Assessment of Associated Risks in the West-Cameroon Highlands (Central Africa). 8th International Association of Geomorphologists, Paris, 654.

[12] Nechia Wantim, M., Kervyn, M., Ernst, G., Suh, C.E., Jacobs, P. and Marmol, M.A. (2012) Assessing Lava Flow Hazard at Mount Cameroun Volcano, West-Central Africa with a Parabolistic Maximum Slope Model. The Magmatic Rifting and Active Volcanism Conference, Addis Ababa, 11-13 January 2012, 163.

[13] Gountié Dedzo, A., Kamgang, P., Njonfang, E., Zangmo Tefogoum, G., Kagou Dongmo, A. and Nkouathio, D.G. (2012) Mapping and Assessment of Volcanic Hazards Related to the Ignimbritic Eruption by AMS in Bambouto Volcano (Cameroon Volcanic Line). The Open Geology Journal, 6, 72-84.

[14] Guedjeo, C.S., Kagou Dongmo, A., Ngapgue, F., Nkouathio, D.G., Zangmo Tefogoum, G., Gountié Dedzo, M. and Nono, A. (2013) Natural Hazard along the Bamenda Escarpment and Its Environments: The Case of Landslide, Rock Fall and Flood Risks (Cameroon Volcanic Line, North-West Region). Global Advanced Research Journal of Geology and Mining Research, 2, 15-26.

[15] Toteu, S.F., Van Schmus, W.R., Penaye, J. and Michard, A. (2001) New U-Pb and Sm-Nd Data from North-Central Cameroon and Its Bearing on the Pre-Pan African History of Central Africa. Precambrian Research, 108, 45-73. http://dx.doi.org/10.1016/S0301-9268(00)00149-2

[16] Nzolang, C., Kagami, H., Nzenti, J.P. and Holtz, F. (2003) Geochemistry and Preliminary Data on the Neoproterozoic Granitoids from the Bantoun Area, West Cameroon: Evidence for a Derivation from a Paleoproterozoic to Archeancrust. Polar Geoscience, 16, 196-226.

[17] Nzolang, C. (2005) Crustalevolution of the Preacambrianbasement in West Cameroon: Inference from Geochemistry, Sr-Nd and Experimental Investigation of Some Granitoids and Metamorphic Rocks. Ph.D. Thesis, Graduate School of Science and Technology, Niigata University, Niigata, 207 p.

[18] Zangmo Tefogoum, G., Nkouathio, D.G., Kagou Dongmo, A., Wandji, P., Gountie Dedzo, M., Kamgang, P. and Nono, A. (2013) Characterization of the Geoheritage of Lefo Caldera and Its Surroundings (Mount Bamenda, Cameroon Volcanic Line). The 24th Colloquium of African Geology, Addis Ababa, 7-13 January 2013, 344.

[19] Kamgang, P., Chazot, G., Njonfang, E. and Tchoua, F. (2008) Geochemistry and Geochronology of Mafic Rocks from Bamenda Mountains (Cameroon): Source Composition and Crustal Contamination along the Cameroon Volcanic Line. Comptes Rendus Geoscience, 340, 850-857. http://dx.doi.org/10.1016/j.crte.2008.08.008

[20] Kamgang, P., Njonfang, E., Nono, A., Gountié Dedzo, M. and Tchoua, F.M. (2010) Petrogenesis of a Silicic Magma System: Geochemical Evidence from Bamenda Mountains, NW Cameroon, Cameroon Volcanic Line. Journal of African Earth Sciences, 58, 285-304.

[21] GountiéDedzo, M., Nédélec, A., Njanko, T., Nono, A., Font, E. and Launeau, P. (2011) Magnetic Fabrics and Sources of Miocene Ignimbrites from West-Cameroon. 23rd Colloquium of African Geology, Johannes Burg, 8-14 January 2011, 164.

[22] Ngounouno, I. (1998) Chronologie, Pétrologie et cadre géodynamique du magmatisme cénozoïque de la Ligne du Cameroun. In: Geosc. Au Cameroun, Ed., collect. Géocam, 1/1998, Press of University of Yaounde I, 169-184.

[23] Suchel, J.B. (1972) La répartition des pluies et les régions pluviométriques au Cameroun. Contribution à l’étude des climats de l'Afrique tropical. MESIRES-ORSTOM, Yaoundé, 260 p.

[24] Olivry, J.C. (1986) Fleuves et Rivières du Cameroun. Mesres-Orstom, Paris, 733.

[25] Suchel, J.B. (1988) Les climats du Cameroun. Thèse de Doct. D’Etat, University of St Etienne, Saint-Étienne, 4 Volumes, $1188 \mathrm{p}$.

[26] Varnes, D.J. (1978) Slopemovement Types and Processes. In: Schuster, R.L. and Krizek, R.J., Eds., Special Report 176: Landslides: Analysis and Control Transportation and Road Research Board, National Academy of Science, Washington 
DC, 11-33.

[27] Ayalew, L. (2000) Factors Affecting Slope Stability in the Blue Nile Basin. In: Bromhead, M., Dixon, N. and Ibsen, M., Eds., Landslides: In Research, Theory and Practice, Thomas Telford, Cardiff, 101-106.

[28] Nyssen, J., Poesen, J., Moeyersons, J., Deckers, J., Haile, M. and Lang, A. (2003) Human Impact on the Environment in the Ethiopian and Eritrean Highlands-A State of the Art. Earth-Science Reviews, 64, 273-320.

[29] Wolle, W.M. and Hachich, W. (1989) Rain-Induced Landslides in Southeastern Brazil. Proceedings of the 12th International Conference on Soil Mechanics and Foundation Engineering, Vol. 3, Rio de Janeiro, 1639-1642.

[30] Alcántara-Ayala, I. (2002) Geomorphology, Natural Hazards, Vulnerability and Prevention of Natural Disasters in Developing Countries. Geomorphology, 47, 107-124. http://dx.doi.org/10.1016/S0169-555X(02)00083-1 
Scientific Research Publishing (SCIRP) is one of the largest Open Access journal publishers. It is currently publishing more than 200 open access, online, peer-reviewed journals covering a wide range of academic disciplines. SCIRP serves the worldwide academic communities and contributes to the progress and application of science with its publication.

Other selected journals from SCIRP are listed as below. Submit your manuscript to us via either submit@scirp.org or Online Submission Portal.
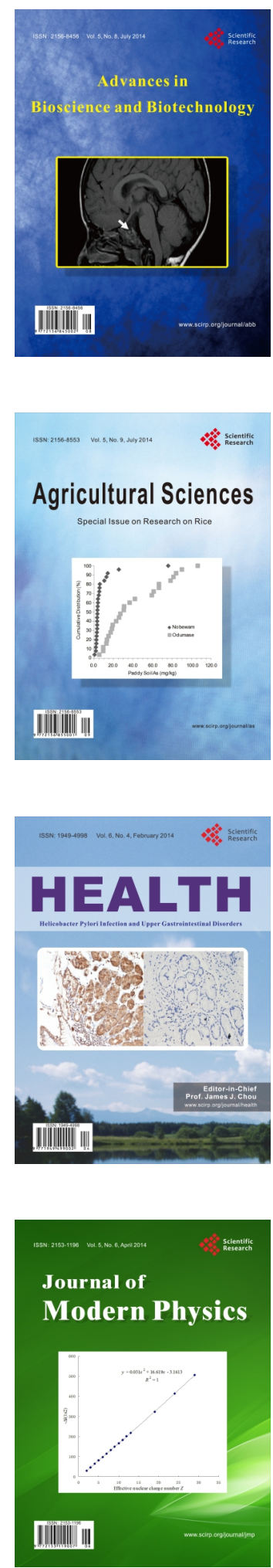
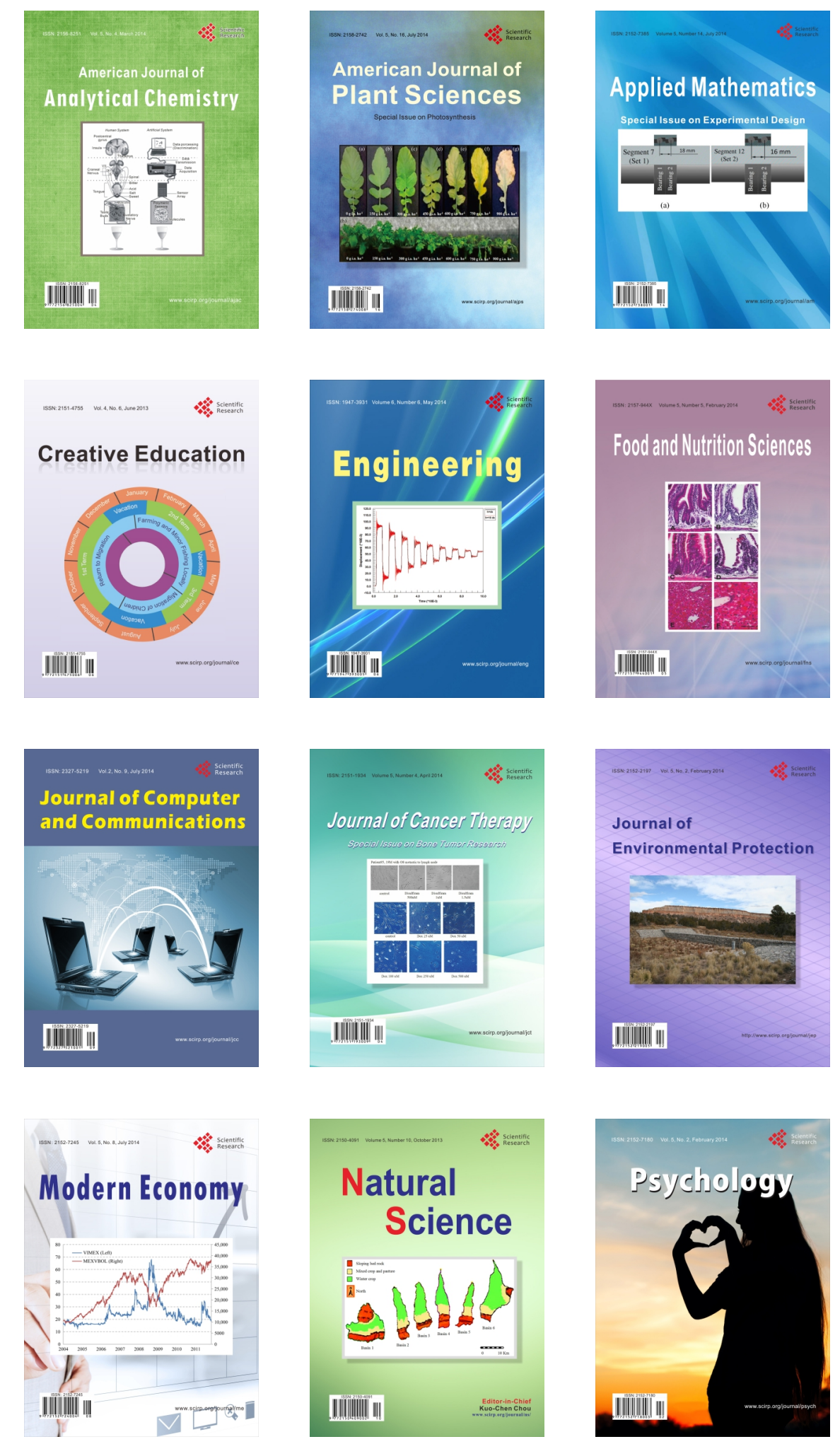